1 Expresión utilizada por Alfredo Molano en el artículo "Mochilas al viento", publicado en el diario El Espectador, 2009.

2 El grupo de investigadores cuenta con un importante trayectoria con trabajos como: Impacto de la aplicación del diseño en la artesanía tradicional (1999), Las escuelas de artes y oficios en Colombia y la recuperación del patrimonio cultural de los oficios (2006), Derechos de propiedad intelectual sobre el Arte Manual Kamsá (2009), Artesanos desplazados y desplazados artesanos en Pasto y Sibundoy: rupturas, continuidades e innovaciones identitarias en contexto de guerra (2010), Diseño participativo como estrategia de competitividad en la cestería de la comunidad artesanal del Valle de Tenza (2010),

Relaciones de poder de los campos artesanales en territorios de desplazamiento forzado por el conflicto armado: casos de estudio en Pasto y Sibundoy (2011). También los autores han publicado diversos textos como: Reflexiones en torno a la artesanía y el diseño en Colombia (2003), Conspirando con los artesanos: crítica y propuesta al diseño en la artesanía (2006), Diseño socialmente responsable: ideología y participación (2009), Las escuelas de Artes y Oficios en Colombia, 1860-1960 (2013) y diversos artículos y conferencias nacionales e internacionales. Además han participado en la creación y puesta en marcha del diplomado en Creación Cultural: Diseño y Artesanía y de la iniciativa colectiva Autonomía Artesanal para el encuentro de los pueblos: territorio vida y dignidad. Pueblo Kamsá.

\section{Riesgos y tensiones de las marcas colectivas y denominaciones de origen de las creaciones colectivas artesanales indígenas}

\author{
Gloria Stella Barrera Jurado \\ Ana Cielo Quiñones Aguilar \\ Juan Carlos Jacanamijoy Juajibioy
}

"Un robo cultural simple y llano"1

Este estudio se presenta como resultado de diversas reflexiones críticas de los investigadores con miembros de algunos pueblos indígenas en torno a las creaciones artesanales colectivas ${ }^{2}$. Los conocimientos artesanales indígenas tienen características muy complejas, en primera instancia, porque son resultado de procesos de creación anónimos y colectivos, y además porque no parten de un principio de propiedad privada ni exclusivamente de una dimensión económica, sino de dinámicos entretejidos cosmogónicos, sociales, técnicos, políticos y ambientales imbricados en la cultura. Estos conocimientos y prácticas han sido preservados por los diversos pueblos indígenas y adaptados a los cambios y dinámicas sociales. La economía actual valora los conocimientos, prácticas y recursos indígenas porque los considera susceptibles de ser convertidos en productos de masas, especialmente en el campo genético, farmacéutico, alimenticio y en los ámbitos simbólicos como los de la artesanía.

El sistema jurídico para la protección de la propiedad intelectual se fundamenta en los principios del pensamiento liberal, de la realización personal, de la innovación centrada en intereses económicos y se expresa a través de la regulación de la propiedad industrial y los derechos de autor. La protección de los conocimientos asociados a las creaciones artesanales indígenas se ha adaptado al sistema de propiedad industrial, lo que ha propiciado graves problemas de comprensión de sus orígenes, cosmovisiones, rituales, formas de creación, transmisión de conocimiento, organización de la producción, circulación y uso objetual. Además, el carácter individualista de la propiedad intelectual se opone al colectivo del conocimiento tradicional artesanal.

Alfredo Molano presenta una crítica a los diseñadores que trabajan con pueblos indígenas artesanales -como es el caso de los Wayuu- pues en su actividad profesional suscitan que "los dibujos originales que representan sus caminos, sus clanes, sus muertos, la vulva de la vaca, los intestinos de

* Cómo citar este artículo: Barrera, G., Quiñones, A. y Jacanamijoy, J. (2014). Riesgos y tensiones de las marcas colectivas y denominaciones de origen de las creaciones colectivas artesanales indígenas. Apuntes, 27(1), 36-51. http://dx.doi. org/10.11144/Javeriana.APC27-1.rtmc 


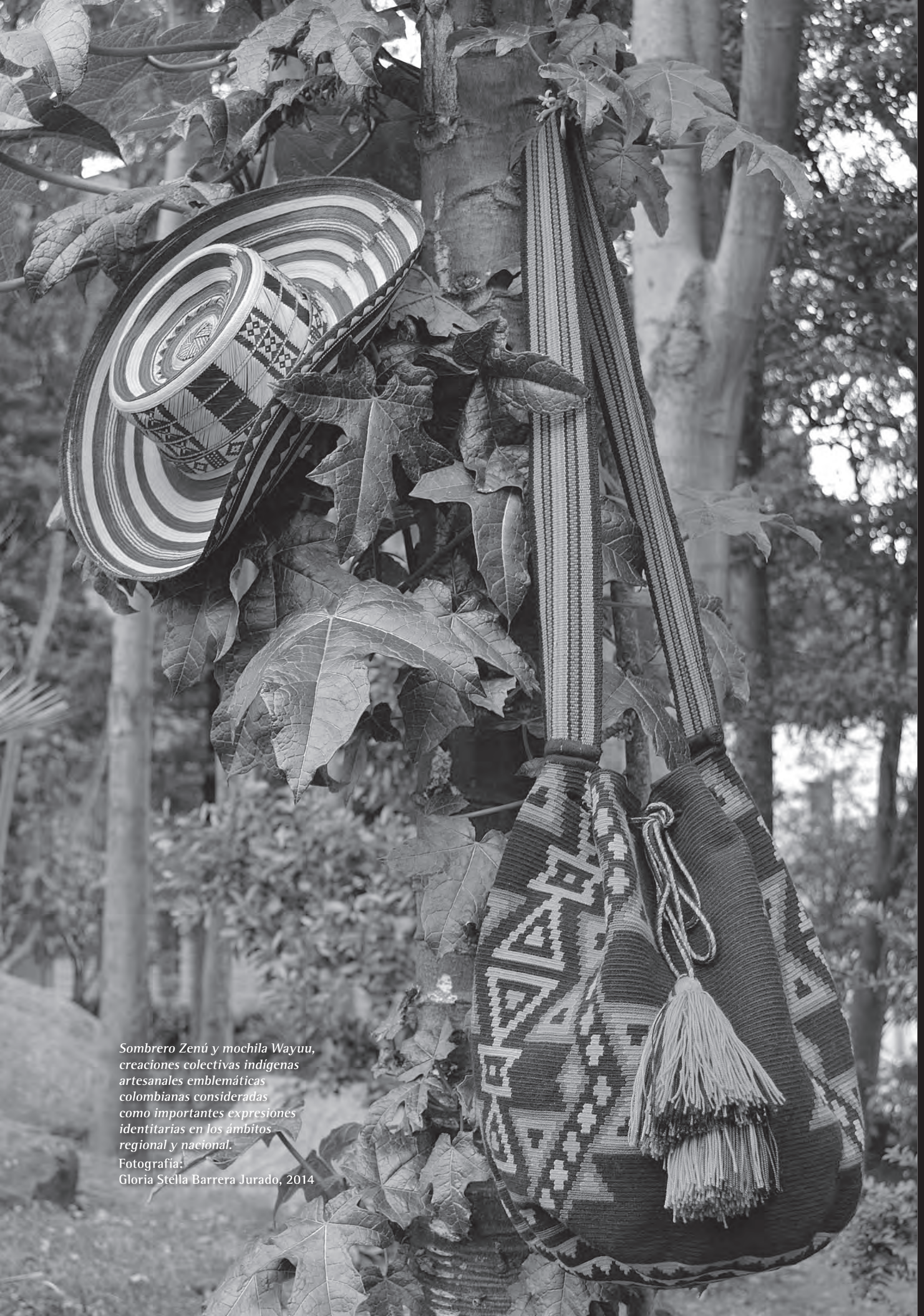




\section{Riesgos y tensiones de las marcas colectivas y denominaciones de origen de las creaciones colectivas artesanales indigenas}

Risks and tensions of collective trademarks and certificates of origin of collective indigenous handcrafted creations

Riscos e tensões das marcas coletivas e denominações da origem das criações artesanais coletivas indigenas

Gloria Stella Barrera Jurado

Profesora, Pontificia Universidad Javeriana, Colombia. gbarrera@Javeriana.edu.co

Ana Cielo Quiñones Aguilar

Profesora, Pontificia Universidad Javeriana, Colombia. quinonesa@Javeriana.edu.co

Juan Carlos Jacanamijoy Juajibioy

Profesor, Pontificia Universidad Javeriana, Colombia. jjacanamijoy@Javeriana.edu.co

Resumen

Este trabajo se realizó como parte del proceso de la investigación "Protección de las creaciones artesanales colectivas indigenas desde el enfoque de derechos humanos", la cual se viene elaborando para comprender e interpretar las dinámicas de las creaciones indígenas y sus posibles formas de protección. Durante mucho tiempo los conocimientos tradicionales indígenas fueron de interés solo para algunos intelectuales, artistas y científicos sociales, mientras que para otros eran invisibles, despreciados y concebidos como atrasados. Hoy para diversos actores sociales adquieren un gran valor al considerarse como significativas mercancías para la explotación comercial.

Actualmente contamos con una gran preocupación por lo que hemos denominado en este trabajo las apropiaciones consentidas y las apropiaciones no consentidas de estas creaciones por parte del Estado, empresas, artistas y diseñadores, por lo cual realizamos una aproximación a dos casos de estudio que han tenido importante relevancia mediática. Este análisis suscitó más preguntas que respuestas.

Palabras clave: artesanos; propiedad intelectual; marca colectiva; denominación de origen; apropiación: Colombia

\section{Abstract}

This study was carried out as part of the research process on the "Protection of collective indigenous handcrafted creations from a Human Rights perspective". The aim of this research is to understand and interpret the dynamics of indigenous creations and possible ways to protect them. For a long time traditional indigenous knowledge was of interest only to some intellectuals, artists and social scientists while for others it was invisible, disregarded and considered backward. Today this knowledge takes on a great value for several social actors as it is being considered a significant merchandise for commercial exploitation.

At present there is a deep preoccupation for what we have called in this study the permitted appropriations and the non-permitted appropriations of these creations on the part of the Colombian State, enterprises, artists and designers. That is why in this study we approach two cases with an important media relevance. This analysis aroused more questions than answers.

Keywords: artisans; intellectual property; collective trademark; origin denomination: appropriation; Colombia

Resumo

O trabalho se realizou como parte do processo de investigaçầo "Proteção das criaçōes artesanais coletivas indígenas sob o enfoque dos Direitos Humanos". A pesquisa é desenvolvida para compreender e interpretar as dinâmicas da arte indigena e seus possiveis tipos de proteção. Por muito tempo, os conhecimentos tradicionais indigenas foram apenas valorizados por poucos intelectuais, artistas e cientistas sociais. Para outros foram invisíveis, despreciados e entendidos como atrasados. Hoje, para muitos atores sociais tais conhecimentos tradicionais, possuem muito valor como mercadoria para a exploração e troca.

Recepción: 7 de marzo de 2013

Aceptación: 20 de septiembre de 2013 Disponible en linea: 2 de enero de 2014
Atualmente, temos uma grande preocupaçāo com o que chamamos neste trabalho de apropriaçōes consensuais e das apropriaçōes não consensuais destas criaçōes pelo Estado, empresas, artistas e designers. Por isso, realizaremos uma abordagem em dois estudos de caso com relevância mediática significativa. A análises, levantou mais perguntas que respostas.

Palavras chaves: artesanato; propriedade intelectual; marca coletiva; denominação de origem; apropriação; Colômbia

doi:10.11144/Javeriana.APC27-1.rtmc 
burro, el hígado de la tortuga, serán reemplazados por cuadritos, rayitas, bolitas, adornitos brillantes y, por supuesto, llevarán estampada la firma del autor (...) un robo cultural simple y llano. Como tantos otros" (Molano, 2009, p. 39). La presencia cada vez mayor de diseñadores industriales, diseñadores gráficos, diseñadores de moda y de otros profesionales creativos inquietan a los artesanos de los pueblos indígenas, quienes tienen incertidumbres acerca del uso que estos actores externos hacen de sus conocimientos y prácticas al crear productos a partir de los referentes culturales indígenas sin su consentimiento, reconocimiento ni retribución.

El arte indígena se reproduce en alfombras, camisetas y tarjetas de felicitación; músicas tradicionales se fusionan con ritmos de baile tecno-house para producir álbumes "superventas" de "músicas del mundo"; alfombras hechas a mano y objetos de artesanía se copian y se venden como "auténticos"; se patenta el procedimiento de manufactura de un instrumento musical tradicional; vocablos y nombres indígenas se registran como marcas y se utilizan comercialmente (OMPI, s.f., p. 1).

Los pueblos indígenas han sufrido el despojo material y simbólico de sus territorios, sus recursos $\mathrm{y}$, actualmente, de sus conocimientos. Las estructuras de gobierno y autoridad, los sistemas jurídicos ancestrales, las estrategias de intercambio, así como los esquemas tradicionales de trabajo colectivo han sido transformados cuando los adoptan formas de vida de la "sociedad mayor" que privilegian principios, valores y normas culturales vinculadas a la prevalencia del interés particular, la propiedad privada y los principios económicos especulativos.

Pese a que para la protección de las creaciones artesanales en Colombia se han implementado aspectos vigentes de la propiedad industrial, como son las marcas colectivas y las denominaciones de origen, al parecer, estos mecanismos han resultado insuficientes, ineficaces o inoperantes para la protección de los conocimientos tradicionales artesanales de los pueblos indígenas debido a las situaciones complejas de "apropiaciones no consentidas" en las cuales los creadores no han autorizado la producción, reproducción o transformación

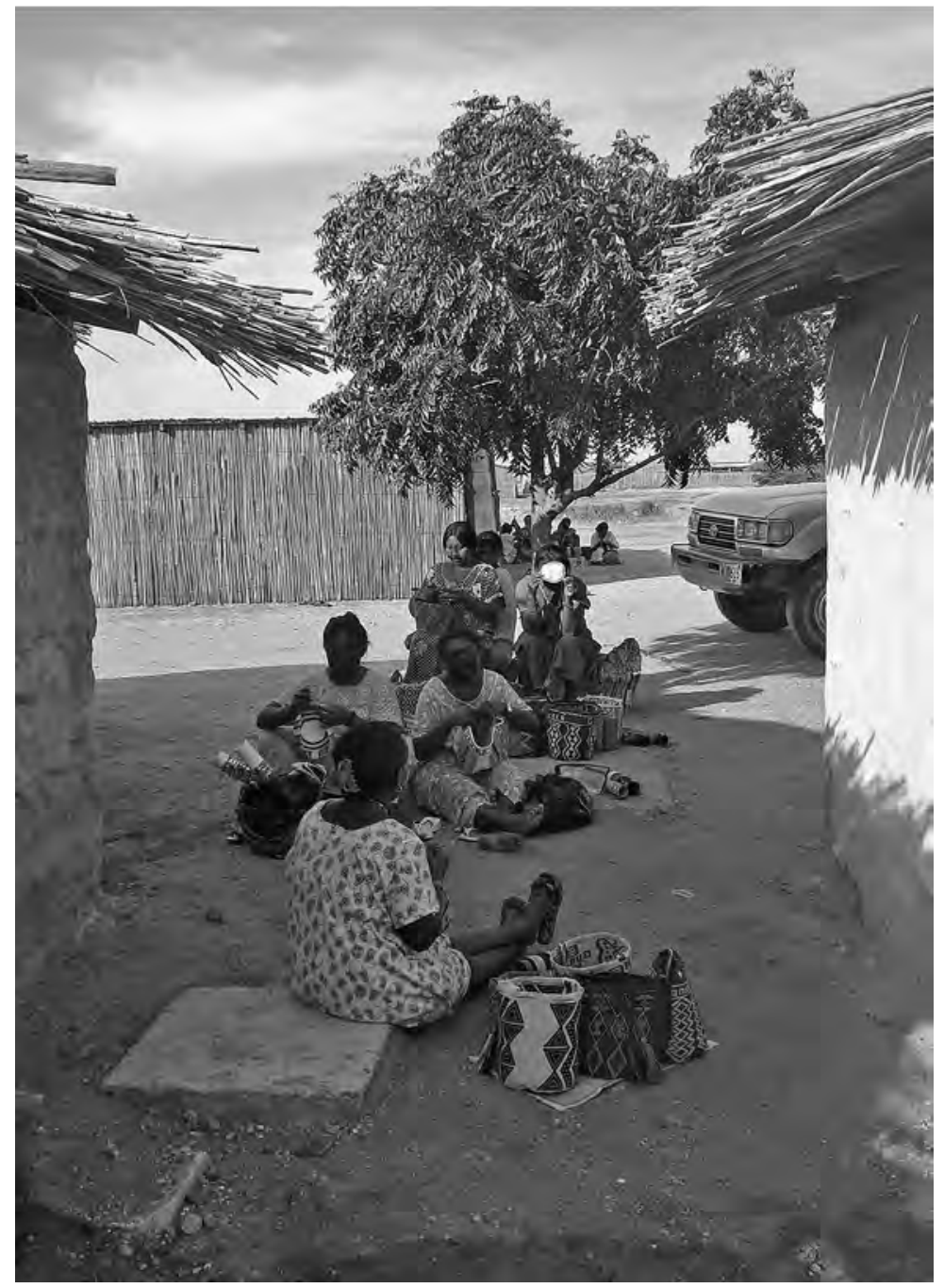

de sus creaciones artesanales completas ni de partes o componentes de las mismas, ni el uso y/o aplicación de sus aportes técnicos, simbólicos o estéticos a otros actores sociales; y de "apropiaciones consentidas" en las cuales bajo determinadas y apremiantes condiciones los creadores han autorizado de manera tácita o expresa la producción, reproducción o transformación de sus creaciones artesanales, el uso y/o aplicación de sus aportes técnicos, simbólicos o estéticos a otros actores sociales.

Por ello, hoy es importante reflexionar y comenzar a andar sobre rutas esperanzadoras de largo aliento, que posibiliten la protección y respeto de las creaciones colectivas artesanales indígenas a partir de sus leyes de origen. Este es un reto complejo que se compromete con los creadores indígenas, para que cuenten con el control sobre su propio patrimonio y decidan acerca de sus cosmovisiones, conocimientos, prácticas, usos y aplicaciones.
Figura 1:

Mujeres Wayuu en proceso de cocreación y elaboración individual y colectiva de sus mochilas Fotografía: Gloria Stella Barrera Jurado, 2007 
3 La Organización Mundial de la Propiedad Intelectual, ompi, es un foro mundial especializado en propiedad intelectual adscrito a la Organización de Naciones Unidas.

4 Las normas marco en Colombia sobre derechos de autor y propiedad industrial son la Ley 23 de 1982 o Ley de Derechos de Autor, sus Decretos Reglamentarios 44 de 1993 y 460 de 1995 y la Decisión 486 de 2000. Tanto los derechos de autor, como la propiedad industria tienen una duración limitada en el tiempo, los derechos de autor están protegidos durante la vida del autor $y$ ochenta años más (Ley 23 de 1982, artículo 21); la propiedad industrial, tratándose de marcas comerciales, ha definido una protección jurídica de diez años prorrogables por períodos sucesivos de diez años más (Decisión 486, artículo 152), tiempo en el cual las marcas pueden ser objeto de contratos o ser adquiridas por sucesión.5

5 El Decreto Reglamentario 258 de 1987 de la Ley 36 de 1984, Ley del Artesano, define que la artesanía indígena es: "Aquella en que el aborigen utilizando sus propios medios transforma dentro de sus tradiciones, en objetos de arte y funcionalidad los elementos del medio ambiente en que vive para así satisfacer necesidades materiales y espirituales, conservando sus propios rasgos históricos y culturales". Esta concepción actualmente propicia diversos debates en el mundo académico porque no da cuenta de la diversidad, de la complejidad y cambios del universo artesanal indígena colombiano.

6 Decisión 486 de 2000, Título VIII, artículo 180.Comunidad Andina de Naciones.

7 Decisión 486 de 2000, Título XII, Capítulo I, artículo

201, De las indicaciones geográficas. Comunidad Andina de Naciones.

8 Proyecto orientado a: "Dotar al sector artesanal de las herramientas legales en Propiedad Intelectual, im plementar el uso de marcas colectivas, de certificación y denominaciones de origen y fortalecer la innovación y comercialización de las artesanías emblemáticas para su
Creaciones artesanales indígenas: entre marcas colectivas y denominaciones de origen

La Constitución Política de Colombia regula el acceso a la propiedad privada a través del artículo 58, "Se garantizan la propiedad privada y los demás derechos adquiridos con arreglo a las leyes civiles, los cuales no pueden ser desconocidos ni vulnerados por leyes posteriores". La propiedad intelectual es un tipo especial de propiedad regulada también constitucionalmente, para la cual se establece una duración limitada en el tiempo y unas normas jurídicas especiales.

Según la OMPI (s.f.) ${ }^{3}$ : "La propiedad intelectual se relaciona con las creaciones de la mente: invenciones, obras literarias y artísticas, así como símbolos, nombres e imágenes utilizados en el comercio" cuyas dos vertientes jurídicas más destacadas son: la propiedad industrial y los derechos de autor.

La propiedad industrial se define como una categoría jurídica orientada a proteger las creaciones del intelecto humano que posean utilidad industrial, y los derechos de autor protegen igualmente dichas creaciones en las áreas de la ciencia, el arte y la literatura.

La propiedad industrial, a su vez, distingue dos grandes categorías de protección de derechos: el derecho de los signos distintivos y el derecho de las nuevas creaciones. En la primera categoría se encuentra inmerso lo que en el lenguaje juridico se conoce como Derecho Marcario, disciplina que comprende la protección jurídica de aquellos productos o servicios del mercado y que se identifican a través de signos distintivos, entre otros, marcas comerciales, marcas colectivas, marcas de certificación, lemas comerciales, nombres comerciales, rótulos o de señas comerciales, indicaciones geográficas que incluye tanto denominaciones de origen como indicaciones de procedencia.

Mientras que en la categoría de derechos de autor pueden distinguirse los derechos de los autores ${ }^{4}$ propiamente dichos y los derechos conexos, asociados a los derechos de los productores fonográficos, organismos de radiodifusión y los derechos de los intérpretes y ejecutantes.

A efectos de comprender un poco más la regulación de las "artesanías indígenas" 5 a través de normas jurídicas de la Comunidad Andina, es necesario acercarse a definición de marcas colectivas y denominaciones de origen. Las marcas colectivas se encuentran definidas como "todo signo que sirva para distinguir el origen o cualquier otra característica común de productos 0 servicios pertenecientes a empresas diferentes y que lo utilicen bajo el control de un titular"6; y las denominaciones de origen son "una indicación geográfica constituida por la denominación de un país, de una región o de un lugar determinado, o constituida por una denominación que sin ser la de un país, una región o un lugar determinado se refiere a una zona geográfica determinada, utilizada para designar un producto originario de ellos y cuya calidad, reputación u otras características se deban exclusiva o esencialmente al medio geográfico en el cual se produce, incluidos los factores naturales y humanos"7.

La artesanía indígena ha sido considerada por la "sociedad mayor" como una actividad manual ejercida por los pueblos originarios, a través de la cual ellos obtienen el sustento de sus familias en un entorno de precariedad técnica y cultural. En la actualidad, y principalmente por la intervención de los estudiosos del arte, el diseño y el derecho, se pretende otorgarle un valor eminentemente comercial e insertarle en los mercados mundiales de la moda y la cultura, ejerciendo nuevas formas de colonización en lugares inhóspitos del territorio nacional e internacional.

A través del proyecto Implementación de Derechos de Propiedad Intelectual de las Artesanías Emblemáticas de Colombia ${ }^{8}$, ejecutado por Artesanías de Colombia, el gobierno nacional definió que la protección más adecuada para la artesanía elaborada por los pueblos indígenas era la otorgada por las marcas colectivas y las denominaciones de origen, y diseñó un procedimiento administrativo que se realiza ante la Superintendencia de Industria y Comercio en el que personas jurídicas naturales y estatutarias, incluidos los Resguardos Indígenas, pueden acceder al registro de marcas bajo la titularidad del Estado sobre formas asociativas de trabajo.

Este proyecto, en un primer momento, contactó a las comunidades artesanas y sus autoridades para obtener su participación y su consentimiento en un espacio de sensibilización, posteriormente capacitó a los artesanos indígenas sobre los derechos de autor y en formas asociativas de trabajo bajo el argumento, al parecer, de una "protección legal colectiva” de sus artesanías. En un tercer momento, tras un estudio jurídico especializado, definió la protección legal a tra- 
vés de marcas colectivas y denominaciones de origen mediante la consolidación de "los datos básicos del oficio, la tradición, reconocimiento en el mercado y su nivel de asociatividad" (Artesanías de Colombia, 2011) y se diseñaron signos distintivos para las comunidades solicitantes. Después planificó la radicación de las solicitudes ante la Superintendencia de Industria y Comercio y el pago de las tasas definidas por la entidad, lo que fue complementado por muestras feriales y actividades de evaluación y alcances del proyecto por parte de los ejecutores.

Existe, asimismo, una propuesta de protección de la artesanía a través del derecho de autor "en la medida en que ésta incorpore una creación artística original, que refleje la identidad del autor" (Artesanías de Colombia, 2010, p. 1), cuando se trata de pintura y escultura aplicada a creaciones artesanales se consideran como obra artística, obra de arte aplicado u obra derivada protegidas por el derecho de autor; no obstante "la relación entre artesanía y derechos de autor no se establece cuando, en la artesanía popular como la indígena, la acción creadora es el resultado de un proceso de aporte y ajustes realizados por las comunidades en el transcurso del tiempo" (Artesanías de Colombia, 2010, p. 2).

$\mathrm{Al}$ considerar las creaciones artesanales indígenas como "obras folclóricas y tradicionales de autores desconocidos”, la Ley 23 de 1982 establece que estas pertenecen al dominio público ${ }^{9}$. Pero esta misma ley ${ }^{10}$ contempla que "el arte indígena, en todas sus manifestaciones, inclusive, danzas, canto, artesanías, dibujos y esculturas pertenece al patrimonio cultural", lo que afecta aún más el ejercicio de control, disposición y uso objetual artesanal de los pueblos indígenas. Actualmente, los pueblos indígenas, sus autoridades y especialmente sus creadores carecen de información suficiente acerca de la titularidad de las marcas colectivas, las denominaciones de origen y la patrimonialización de sus manifestaciones culturales, al ser sometidos a estos modelos foráneos.

El Derecho Mayor o Derecho Propio de los pueblos indígenas ha sido definido por la Organización Nacional Indígena de Colombia, oNIC, en los siguientes términos: "La ley de origen es la ciencia tradicional de la sabiduría y el conocimiento ancestral indígena, para el manejo de todo lo material y espiritual, cuyo cumplimiento garantiza el equilibrio y la armonía de la naturaleza, el orden y la permanencia de la vida, del universo y de nosotros

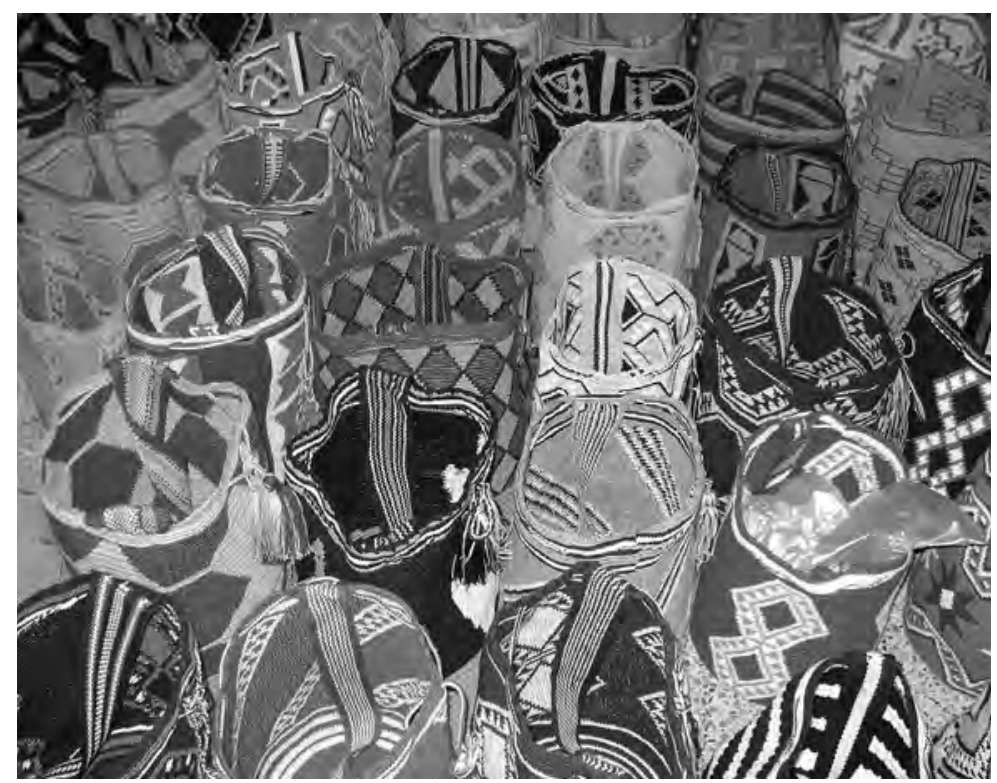

mismos como pueblos indígenas guardianes de la naturaleza” (ACNUDH, s.f., p. 34), en consecuencia, la titularidad de los conocimientos ancestrales de los pueblos indígenas debería estar en cabeza de ellos mismos, de no ser así, se ve amenazada la vida e integridad de estos pueblos debido a la mercantilización de los saberes, la extracción indiscriminada de recursos naturales en los resguardos y el uso irrespetuoso de las creaciones artesanales colectivas.

\section{Las sanciones mediáticas: casos Wayuu y Zenú}

La observación de situaciones conflictivas que han surgido en los últimos años, se realizó en torno a dos estudios de caso: la mochila del pueblo Wa$\mathrm{yuu}^{11}$ y el sombrero vueltiao Zenú y a sus presuntas apropiaciones no consentidas y consentidas. Estas dos expresiones culturales son reconocidas por los colombianos como importantes objetos emblemáticos de las identidades regional y nacional. La importancia del estudio de caso radica en el conocimiento profundo de un fenómeno "refiriendo a una entidad dotada de límites espacio temporales, de una estructura y de una lógica específica de funcionamiento" (Gundermann, 2004, p. 283). El estudio se interesa en lo propio y característico de la experiencia de cada uno de estos pueblos indígenas para luego relacionarlas entre sí.

El análisis de estos casos emerge a partir de la permanente reflexión crítica y colectiva que se viene elaborando con diferentes pueblos indígenas y campesinos, quienes se inquietan
Figura 2:

Diversidad de mochilas Wayuu que expresan la complejidad de la cosmovisión y el pensamiento de este pueblo indígena.

Fotografía:

Gloria Stella Barrera Jurado, 2007

posicionamiento en el mercado nacional e internacional". Disponible en: http://www. artesaniasdecolombia.com. $\mathrm{co/propiedadintelectual/}$

9 El dominio público es un espectro jurídico en donde reposan las obras cuyos derechos de autor hayan expirado, así como las obras folclóricas y tradicionales cuyos autores sean desconocidos y que pueden ser explotadas libremente. 


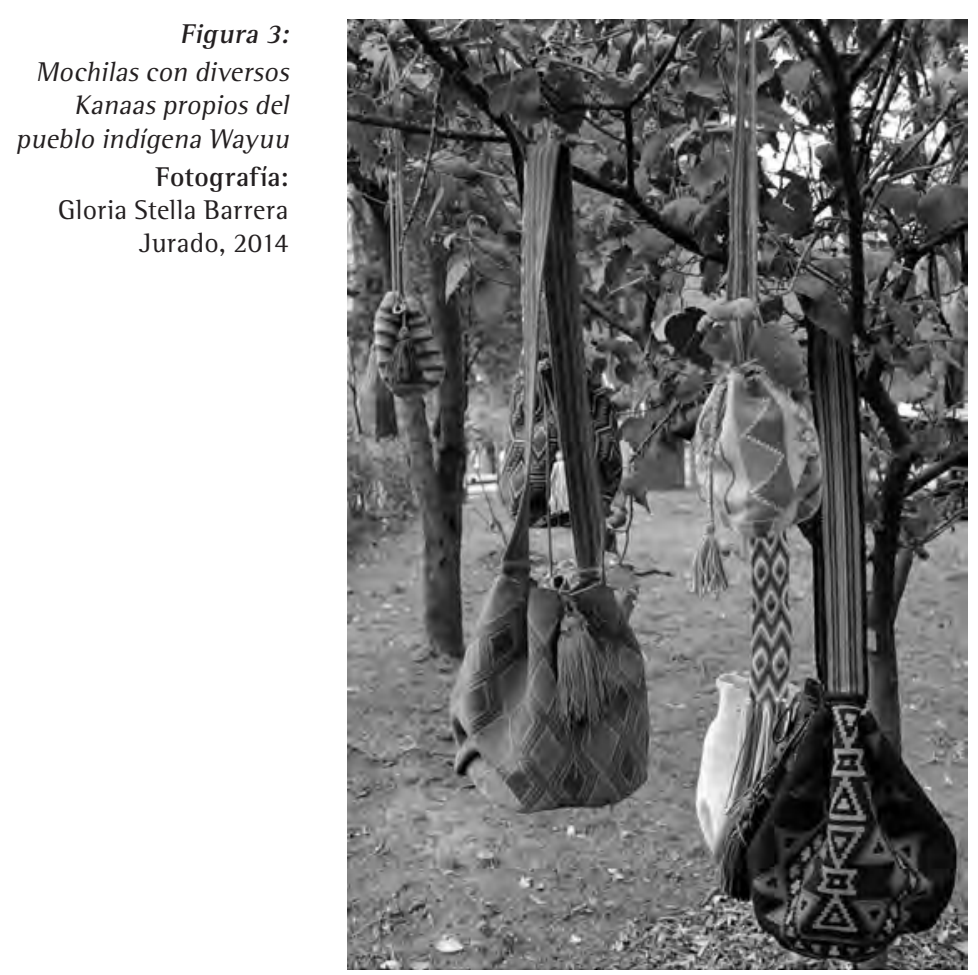

permanentemente ante las situaciones novedosas y poco claras de la protección de sus creaciones colectivas artesanales. Por lo anterior, fue necesario el análisis de coyuntura de estos dos casos de estudio, los cuales tuvieron una gran relevancia mediática y se consideraron como escándalos nacionales, que se caracterizaron por la ambigüedad de su información y la indignación de los pueblos afectados. Este estudio se realizó a partir de fuentes secundarias como periódicos, revistas electrónicas, programas radiales y páginas web, medios de comunicación a través de los cuales circularon estas informaciones. El grupo investigador realizó colectivamente este documento con base en la metodología del círculo de la palabra, alrededor del cual se fueron entretejiendo las preguntas, el análisis crítico y las propuestas que emergieron de este estudio coyuntural.

Para los Wayuu, pueblo de ascendencia Arawak, que habita la península de la Guajira ubicada al norte de Colombia y noroeste del territorio venezolano, con una población de aproximadamente 144.003 habitantes (Hammen, 2003 p. 11) en el territorio colombiano, el tejido es una práctica cotidiana inmersa en su cosmogonía y en el universo de sus conocimientos tradicionales. "Wale'kerü, la araña, enseñó a los primeros Wayuu cómo tramar los hilos y crear los dibujos; ruluma, el comején, luego de hacer una prueba de inteligencia a una joven, le reveló la paciente tarea de remendar las telas" (Ramírez, 1990, p. 5). El aprendizaje del tejido forma parte del rito de iniciación a la pubertad femenina, en el cual las mujeres adultas enseñan a la joven, junto con su rol y sentido fundamental como mujer en esta sociedad, las técnicas de tejido y el significado profundo de los Kanaas ${ }^{12}$ de acuerdo con su cosmovisión.

La mochila, susu como se denomina en el idioma wayuunaiki, es un universo de formas y contenidos importantes de y para la cultura, es conocimiento inmaterial y material que habita conceptual y funcionalmente integrado con la vida, la naturaleza y la sociedad a las que pertenece. Es, además, un lenguaje que expresa la pericia en el oficio que tiene su creadora y por el cual adquiere respeto y prestigio.

La mochila Wayuu ha sido el centro de polémicas en diversas ocasiones. Por su belleza, expresividad y sentido cultural se ha convertido en un objeto de deseo de la moda en las temporadas de primavera-verano especialmente es escenarios internacionales. En 2009 se realizó la noche de gala BeLive13 en Miami, y para ella algunas artesanas Wayuu fueron seleccionadas para interpretar y representar las ideas de diversos diseñadores de moda relevantes en los ámbitos nacionales e internacionales: "En la noche de este jueves se celebra la filantropía, se celebra la generosidad, se celebran los proyectos que cambian vidas, se celebra el arte de las etnias y los conceptos de la moda" (El Espectador - Cultura, 2009)

Así, diversos diseñadores realizaron paralelamente un trabajo de intervención a la mochila Wayuu. Calvin Klein utilizó dos colores básicos, con base en cuero, material que utiliza también en el borde superior y en la gasa o cargadera. Moschino, por su parte, realizó su trabajo con ganchos nodriza en torno a los colores y formas de los tejidos. Silvia Tcherassi aplicó cristales de Swarovski en el bolso y en la gasa siguiendo la geometría del diseño con cristales de los mismos colores de la mochila. La casa italiana Missoni utilizó materiales como cadenas, cuerdas y cordones en lana, algodón y seda. Valentino utilizó colores tierra y negro con flores y lazos negros. Carolina Herrera bordó con piedras color rubí, lentejuelas y brillantes los tejidos blancos y negros con cintas de seda entrelazadas. Óscar de la Renta trabajó con piedras y materiales naturales siguiendo las formas del tejido y los colores, mientras otros diseñadores 
utilizaron materiales como aplicaciones metálicas, tiras de cuero, plumas y herrajes (Revista , 2009).

Este evento fue celebrado por múltiples revistas y aplaudido en diversos periódicos nacionales, salvo por Alfredo Molano quien en una nota del diario colombiano El Espectador escribió un texto que denominó "Mochilas al viento" en el cual expresó:

Las mochilas Wayuu serán las invitadas especiales para ser rematadas en pública subasta. Pero no serán -cosa obvia- las tejidas por las mujeres de la etnia, sino las diseñadas por Óscar de la Renta, Calvin Klein, Missoni, Amelia Toro y Silvia Tcherassi (...) por supuesto, llevarán estampada la firma del autor. Adiós al tejido hecho con fibras de maguey y algodón, a los remates que parecen mandalas, a las gasas con que se guindan, a su peculiar olor a desierto, cabro y trupillo (El Espectador, 2009).

De otra parte, en 2011 la diseñadora Sophie Anderson, del Reino Unido, realizó la colección primavera-verano. La revista Antropologika denunció el 10 de octubre de ese año a la diseñadora inglesa por haber presentado algunas mochilas Wayuu como diseños propios, para lo cual convocaron a opinar en la página de la revista Vogue, como una sanción moral propiciada por los antropólogos en los medios electrónicos, así:

Sophie Anderson, mujer aventurera y experta diseñadora, presentó hoy “sus más recientes diseños, inspirados en el trabajo de una comunidad indígena de la Guajira, Colombia". Para los que sabemos, no existe ninguna diferencia con las originales y éstas son las mismísimas mochilas Wayuu. Varias personas se han pronunciado en la página de Vogue. Te invitamos a que dejes un comentario en ella también, no sólo para hacerle saber a la revista del "plagio" sino para exponer el verdadero valor del trabajo y la creatividad indígena, en un escenario global como la página de la revista Vogue. Sólo esperamos que las mujeres Wayuu reales creadoras y ejecutoras de estos diseños, estén recibiendo un pago a la altura de la clientela que Anderson tendrá en la Semana de la Moda en París (Revista Antropologika, 2011).

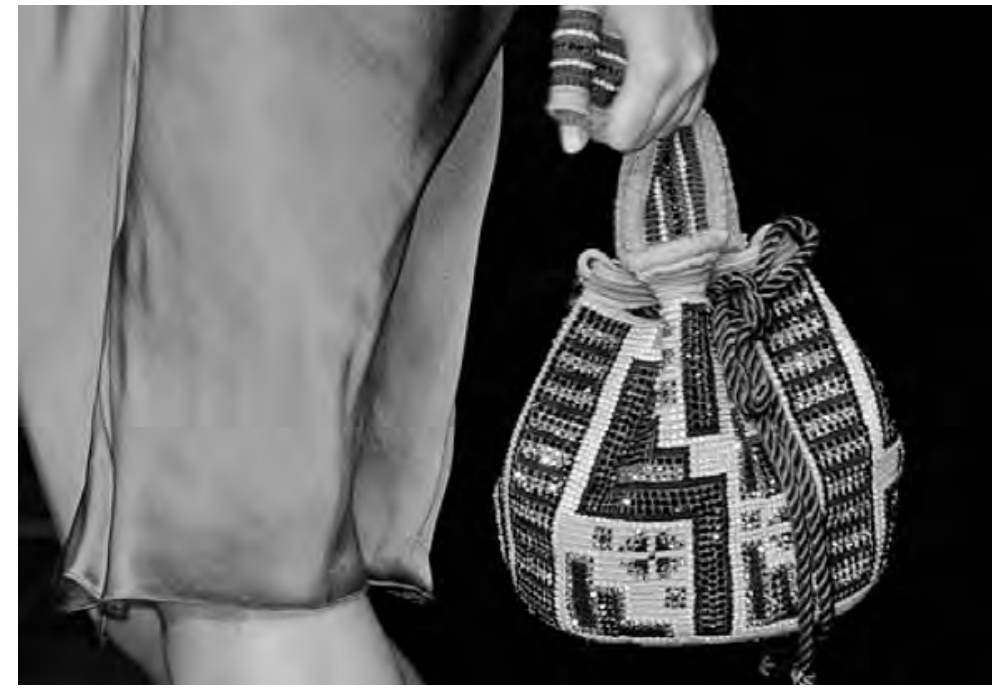

Ya en 2014, Stella Rittwagen, empresaria nacida en Málaga, España, y quien elabora sus objetos a partir de referentes tradicionales y de vanguardia, fue señalada en un programa en vivo la emisora colombiana $L a W$ por un colombiano que habita en Alemania al observar que en un diario español aparecía la publicidad de sus productos con las mochilas Wayuu sin el debido crédito a este pueblo indígena.

La diseñadora Rittwagen vende algunas mochilas monocolor con la gasa o cargadera multicolor como se viene haciendo hace algunos años en el país, pero también vende algunas con los diseños tradicionales pero sin la gasa original, por lo cual incorpora cadenas doradas y hojaletes o una base de cuero con taches dorados. Las mochilas de esta diseñadora se venden directamente en sus almacenes o en otros almacenes de cadena y estos objetos son denominados como "Sacos Wayuu Estrella".

Varias fueron las personas entrevistadas por esa emisora, entre ellas la Gerente General de

Figura 4:

Mochila Wayuu intervenida por la diseñadora Silvia Tcherassi Fuente:

Trends Vip. Style and Fashion insider. Ethnic Chic. Mochilas Wayuu Recuperado el 20 de mayo de 2014 de http:// trendsvip.com/wpcontent/uploads/2012/06/ wayuu-silvia.jpg

Figura 5:

Cartera diseñada por Sophie Anderson a partir de la mochila Wayuu

Fuente:

Mochilas Wayuu on

Pinterest. 77 pins. Sophie Anderson. Fina embroidered clutch. Recuperado el 25 de mayo de 2014 de http://www. pinterest.com/ in/370984088027914837/

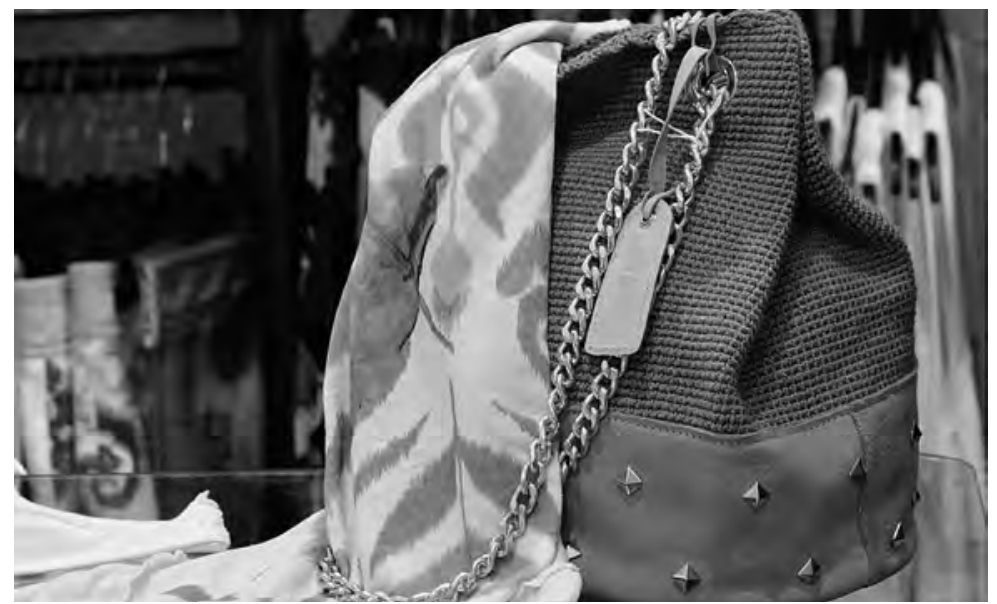


Artesanías de Colombia, quien ante la situación problemática que presentó el oyente, respondió que la mochila Wayuu está protegida por el proyecto de Implementación de los Derechos de Propiedad Intelectual que adelanta esta entidad del Estado, con la marca colectiva Tejeduría Wayuu. También expresó que era imposible proteger este patrimonio colombiano, por lo tanto presentó el reto futuro de analizar este caso con el Instituto Colombiano de Normas Técnicas y Certificación, ICONTEC, y la Superintendencia de Industria y Comercio.

Ante el intenso debate mediático, la diseñadora Rittwagen en un comunicado en sus páginas electrónicas, respondió con una carta abierta en la que expresó:

Que sin perjuicio de cuanto se ha expuesto y en el recto entendimiento de que con la presente comunicación debe quedar zanjado el debate que desgraciadamente se ha producido, Stella Rittwagen s.I. y su diseñador, manifiestan que reaccionan legítimamente frente a cualesquiera descalificaciones y falsedades se propaguen públicamente a partir de ahora (Pulzo, 2014).

La visibilización de las posibles apropiaciones de la mochila Wayuu de la Guajira se ha propiciado desde fuera del país. Las denuncias legítimas han sido motivadas más por sentimientos de indignación y solidaridad con este pueblo, que por una reflexión informada y profunda, por ello se han manejado como escándalos mediáticos que pronto quedan en el olvido. Por su parte, Artesanías de Colombia ha dado respuesta a estas denuncias con discursos semejantes a los de la población indignada, movidos por la pasión y con poca claridad para orientar de manera certera acerca de la real protección de las creaciones colectivas indígenas.

Igualmente, el Superintendente Delegado para la Propiedad Industrial, en la entrevista con la emisora $\mathrm{La} W$, expresó que "el mundo de la propiedad industrial se rige por derechos territoriales, es decir, que tener un derecho de propiedad industrial en un territorio como Colombia no significa que uno tenga ese mismo derecho en otro país". La protección de los derechos de los creadores Wayuu no es tan clara, pues solo existiría en Colombia, Ecuador, Perú y posiblemente en otros países de Suramérica. Para la protección en Europa, dijo el Superintendente, supondría que la Superintendencia de Industria y Comercio tendría que "ir a los 27 países a buscar cuál es la figura más correcta y que se ajuste mejor a las características de este tipo de productos para ver si pueden ser protegidas como marcas colectivas o como una marca de productos o de servicios”. Esta Superintendencia planteó el reto de trabajar con el Protocolo de Madrid que serviría para proteger una marca al realizar esa inscripción internacional. En relación con el documento de Denominación de origen de la Tejeduría Wayuu ${ }^{14}$, este fue entregado al apoderado de la Gobernación, Ricardo Ballesteros Valencia, quien es socio de la firma Palacio y Ballesteros consultores legales.

Es necesario revisar las tensiones y situaciones en que se dan estas posibles apropiaciones, al considerar que algunas piezas propuestas por los diseñadores son realizadas por las propias artesanas Wayuu. Esta dinámica de mandar a hacer objetos intervenidos por diseñadores externos a los artesanos como mano de obra, tiene origen en las metodologías aplicadas por Artesanías de Colombia en todo el territorio nacional en las últimas décadas, en que se ha naturalizado esta relación de dependencia en la creación.

De manera individual algunos miembros pertenecientes al pueblo Wayuu, a través de los medios de comunicación y redes sociales han expresado su indignación frente a estos hechos. Zenaida Pana expresó: "estamos muy tristes porque están plagiando nuestra herencia ancestral (...) estamos indefensos porque no tenemos quién nos defienda y sentimos que los arijunas (no nacidos bajo la etnia Wayuu) se están apropiando de nuestro diseño" (El Heraldo, marzo 29, 2014). Asimismo, Aracelis Pana Epiayú manifestó que "hay muchos extranjeros que vienen a Riohacha y compran una mochila de tipo comercial y se la llevan sin identificarlas como producto colombiano" (El Heraldo, marzo 29, 2014).

De otra parte, Wayunkerra Epinayu, en de su blog electrónico hizo público un extenso artículo denominado "Susu Wayuu, Mochila Wayuu, Wayuu Bag: así se 'roban' el patrimonio cultural Wayuu" en el cual informa diversas situaciones referidas a apropiaciones del conocimiento tradicional y patrimonio cultural del pueblo Wayuu, que vienen sucediendo desde de 2010 por parte de Gobernación de la Guajira. 
hace varios años. En relación con el caso de la diseñadora española Stella Rittwagen, expresó:

Debo declarar que no es el único en el que personas externas y ajenas a nuestra cultura se lucran descaradamente apropiándose de las creaciones indígenas. Esta diseñadora, que conste, declaró que ella misma fue a comprar las mochilas en las rancherías de Riohacha. No obstante, estos agravios se suman a un creciente número de agresiones hacia nuestro patrimonio inmaterial, cultural y artístico (Wayunkerra, 2014).

Refiere también en este texto el caso de la diseñadora Sophie Anderson de la siguiente manera:

Es pertinente también mencionar otras situaciones que con nombre propio afectan al pueblo Wayuu en su conjunto. Por ejemplo, el lanzamiento de la colección primavera-verano 2013 de la diseñadora Sophie Anderson, a quienes los medios electrónicos en el Reino Unido aclamaron por sus diseños "basados en la mochila amerindia”. A la diseñadora Anderson la califican como "de ojo particularmente ecléctico", ya que en cada pieza combina lo moderno con lo antiguo, pero lo que más llama la atención de "su colección" es la vibración de los colores que ella combina en "sus" diseños, diseños y colores que, valga la pena decir, no son otra cosa distinta a lo que llamamos en wayuunaiki: kanaas, dibujos únicos y exclusivos de las artistas Wayuu los cuales ni siquiera existen en patrones impresos, porque cada una de

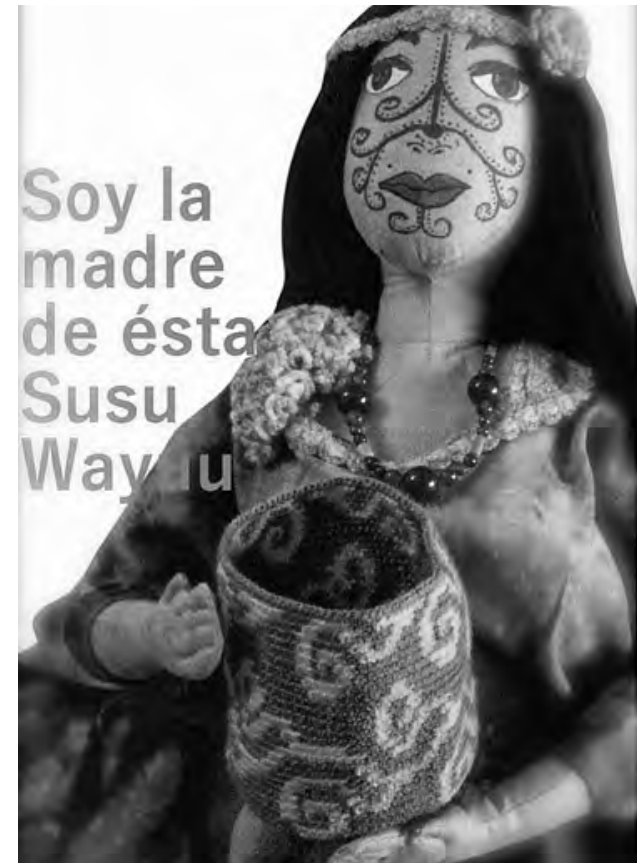

nosotras los lleva guardados en la memoria (Wayunkerra, 2014).

A partir de las reacciones del público en internet, derivadas de este artículo y con la idea de promover acciones en defensa del patrimonio cultural de su pueblo, Wayunkerra Epinayu ideó una campaña a través de las redes sociales en la cual invitaba al pueblo Wayuu a tomar una fotografía de sus mochilas y enviarla a través de los medios electrónicos. Con gran creatividad se impulsó esta campaña a través del diseño de un cartel en que aparece la imagen de una Wayunkerra que sostiene una mochila y dice: "Soy la madre de esta susu Wayuu", lo cual es una clara evidencia de otra cosmovisión, concepción y dimensión de las creaciones artesanales de los pueblos indígenas.

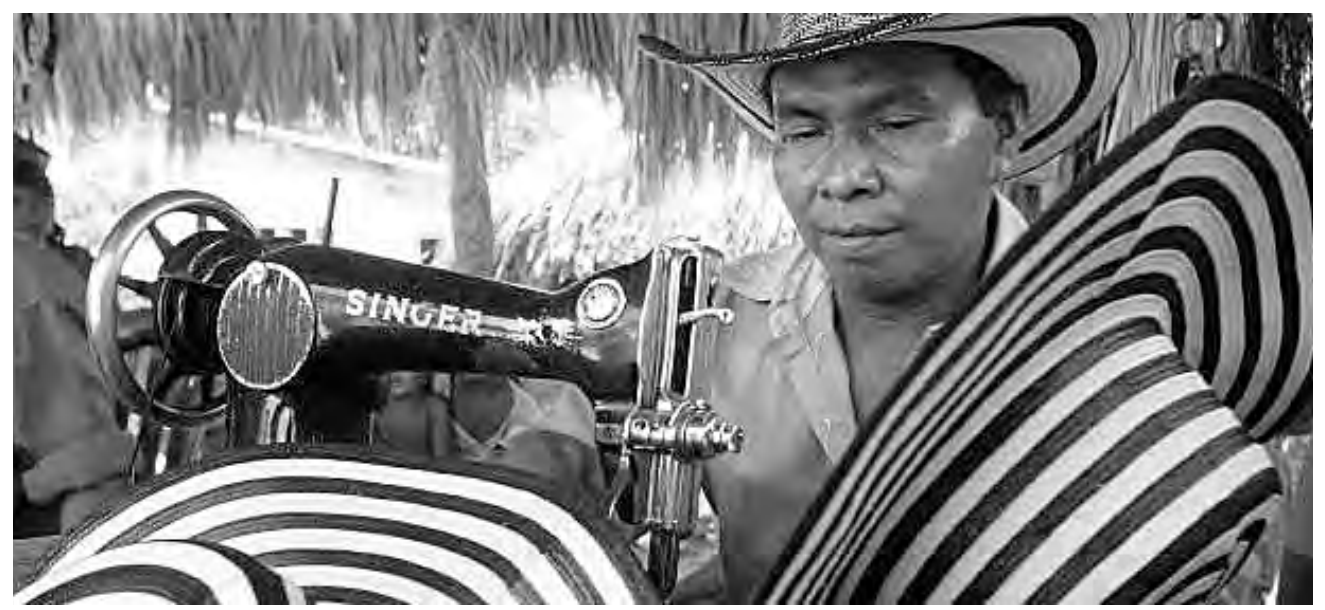

Figura 8:

Artesano Zenú

elaborando el sombrero vueltiao el cual fue producido masivamente en material sintético por empresas chinas

Fuente:

El Colombiano (enero 11, 2013). Indígenas Zenú molestos por imitación china del sombrero vueltiao. Recuperado el 30 de mayo de 2014 de http://www. elcolombiano.com/ BancoConocimiento/1/ indigenas_zenu_ molestos_por_imitacion_ china_del_sombrero_ vueltiao/indigenas_ zenu_molestos_por_ imitacion_china_del_ sombrero_vueltiao.asp 
15 Ley 908 de 2004 "Por la cual se declara Símbolo Cultural de la Nación El Sombrero Vueltiao, y se hace un reconocimiento a la cultura del pueblo Zenú asentada en los departamentos de Córdoba y Sucre".

16 Resolución No. 71097 de 2011 de la Superintendencia de Industria y Comercio.

17 Resolución No. 70661 de la Superintendencia de Industria y Comercio.18 La Superintendencia de

Industria y Comercio ordenó la Resolución No. 439 de 2013 "Por la cual se ordena de manera preventiva la suspensión de la producción, comercialización y venta de un producto [el sombrero vueltiao] y se realizan advertencias al consumidor".

Figura 9:

Sombrero tejido a mano en caña flecha por los tejedores del pueblo Zenú

Fuente: Gloria Stella Barrera Jurado, 2014

\section{Caso sombrero vueltiao Zenú}

El pueblo Zenú de los departamentos de Córdoba y Sucre es depositario de una de las creaciones artesanales colombianas más reconocidas nacional e internacionalmente y que denota, no solo la identidad nacional ${ }^{15}$, sino el reconocimiento de un territorio, de una cultura y de sus usos y costumbres: el sombrero vueltiao. Su uso es generalizado en la región caribe y ha sido vestido también por grandes figuras públicas en el ámbito nacional; también ha sido vejado por los grupos armados paramilitares como símbolo de "patriotismo" en su avanzada de conquista territorial macabra en el territorio colombiano. Deportistas, modelos, cantantes, turistas, entre otros, se suman a la gran lista de personas que lucen esta digna pieza artesanal proveniente, principalmente, del Resguardo de San Andrés de Sotavento.

Entre las organizaciones indígenas que tienen presencia en el área de influencia del pueblo Zenú se encuentran: Manexca -Asociación de Cabildos del Resguardo Indígenas Zenú de San Andrés de Sotavento Córdoba y Sucre-, Asocia-

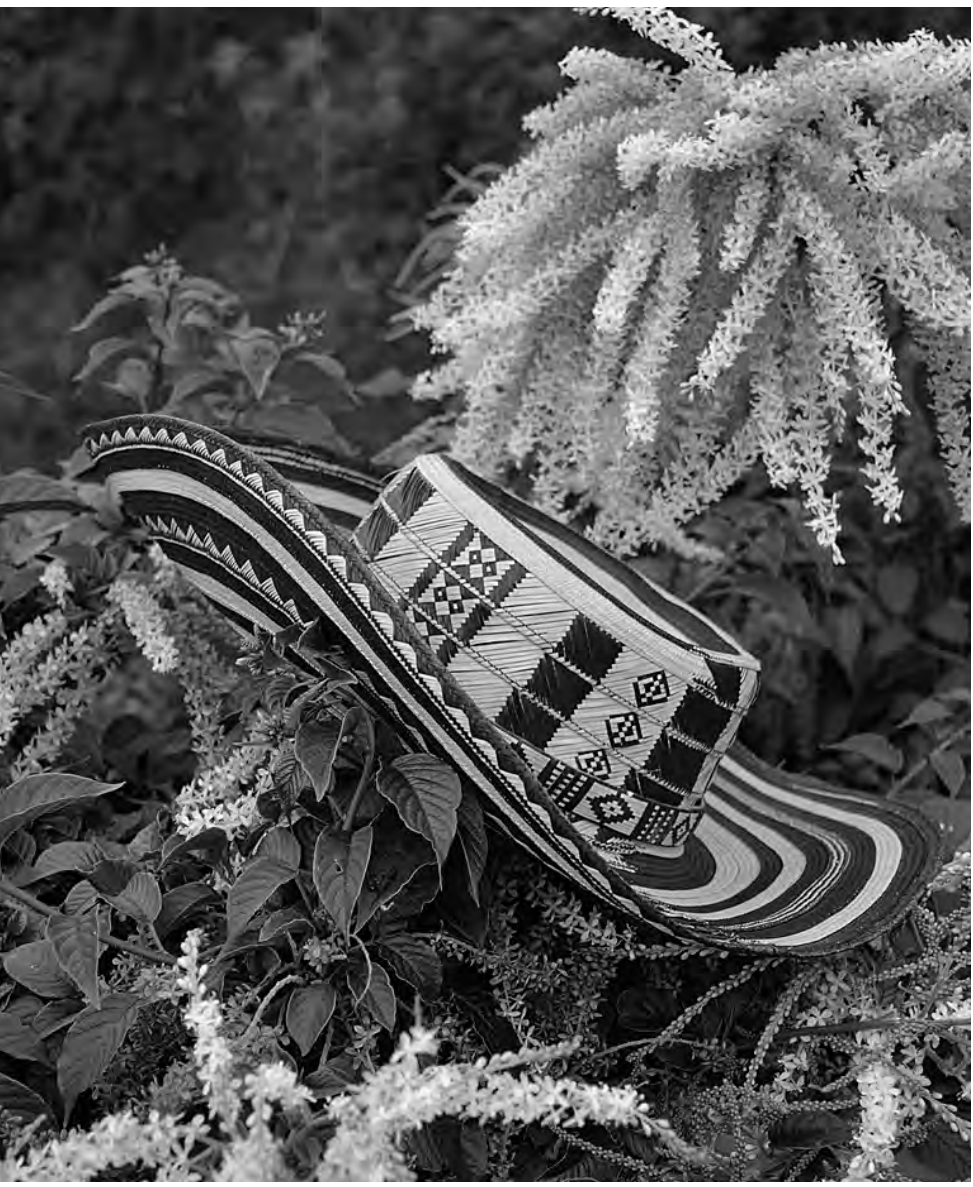




\begin{tabular}{|c|c|c|}
\hline Tipo de relación & Apropiación no consentida & Apropiación consentida \\
\hline \multicolumn{3}{|c|}{ De autor: diseñador, artista, artesano } \\
\hline \multirow{4}{*}{ Actor apropiador } & \multicolumn{2}{|c|}{ De pueblo: pueblo, nación } \\
\hline & \multicolumn{2}{|c|}{ Estatal: Estado } \\
\hline & \multicolumn{2}{|c|}{ Empresarial: empresa nacional } \\
\hline & \multicolumn{2}{|c|}{ Multinacional: empresa internacional o multinacional } \\
\hline
\end{tabular}

Tabla 1: Apropiaciones consentidas o no consentidas por parte de diseñadores, artistas, artesanos, pueblos o naciones, empresas nacionales o internacionales o por parte del Estado.

Fuente: Elaboración del grupo investigador

En síntesis, luego de la aproximación a los dos casos de análisis, se puede decir que a pesar de que los artesanos indígenas Zenú y Wayuu tienen marcas colectivas y denominaciones de origen, la protección de sus creaciones cuenta actualmente con más incertidumbres que con certezas. Han sido más las sanciones de tipo moral y social efectuadas con el apoyo de la sociedad civil que las jurídicas y económicas.

En el caso de la protección de los sombreros vueltiaos, la sanción económica que se dictaminó fue a un productor internacional abstracto ${ }^{18}$, mientras la sanción jurídica en el caso Wayuu es todavía incierta. Las creaciones artesanales indígenas Wayuu y Zenú son la materialización de la cosmovisión propia de estos pueblos indígenas, asociada al territorio, la memoria y el origen, sobre estos objetos recaen procesos de apropiación lesivos a los derechos fundamentales colectivos de los pueblos indígenas y sus órdenes sociales, económicos, políticos, jurídicos, culturales y espirituales.

La apropiación del conocimiento sobre la biodiversidad, por parte de las compañías o instituciones que lo toman de las comunidades locales, transforma los derechos de dichas comunidades -en la mayoría de los casos de países en desarrollo- en derechos privados y monopólicos para tales instituciones, en su mayoría procedentes de países industrializados (Khor, 2003, p. 20).

Los procesos de "apropiación" se pueden dimensionar como asuntos políticos estructurales de ruptura de los órdenes cosmogónicos de los pueblos indígenas y la prevalencia de un orden jurídico superior en desmedro de los primeros y se presentan generalmente como una estructura dicotómica de diálogo entre un actor apropiador y un actor apropiado, que en este caso son los pueblos indígenas que generan o acuerdos de voluntades o imposiciones.
La base sobre la cual se generan esos acuerdos de voluntades es el consentimiento de los actores o contratistas con la subsiguiente creación, modificación o extinción de derechos que, por tratarse de pueblos indígenas y sus derechos fundamentales colectivos, se surca en la obtención del consentimiento previo, libre e informado de las comunidades y autoridades.

En relación con las posibles apropiaciones artesanales, este trabajo propone que se denominen ya sea como apropiaciones consentidas o como apropiaciones no consentidas las cuales se suman a las apropiaciones de conocimientos tradicionales sobre biodiversidad y recursos naturales de los pueblos indígenas.

Las "apropiaciones consentidas" de creaciones artesanales indígenas se entienden como aquellos procesos complejos de negociación en donde fluyen dicotómicamente dos órdenes ideológicos, políticos y jurídicos tendientes a lograr una declaración de voluntad en torno a una creación artesanal indígena, es por ello que se considera que los creadores de maneras tácita o manifiesta autorizan el uso o aplicación de sus creaciones.

Las "apropiaciones no consentidas" se podrían equiparar a complejos procesos en los cuales se pone de manifiesto la vigencia de uno de los órdenes ideológicos, políticos y jurídicos en desmedro del otro, generalmente el primero es el actor con superioridad de condiciones financieras y tecnológicas, por tanto, el segundo es el creador o los creadores, que no autorizan el uso de sus aportes técnicos, simbólico o estéticos por otros actores sociales.

Se observa la posibilidad que ante una misma situación de apropiación artesanal, en un pueblo indígena se presenten de manera simultánea apropiaciones consentidas y apropiaciones no consentidas, situación que da cuenta de las diversas relaciones que pueden tener los miembros de una comunidad ante una institución o un
19 Por ser un derecho colectivo, el titular es el Estado colombiano en cabeza de la sic, pero esta puede delegar la "administración" de la denominación de origen a entidades públicas o privadas que representen a las personas que se dedican a la extracción, producción o elaboración de los productos identificados con la denominación de origen. Consultar en: http://www. sic.gov.co/drupal/denominacion-de-origen. Recuperado el 18 de marzo de 2014. 
mercado, de sus permanentes tensiones sociales y de la complejidad para su estudio.

En esta investigación se identifican casos de probables apropiaciones no consentidas por parte de diseñadores cuando toman las creaciones individuales o colectivas del pueblo Wayuu y las presentan socialmente como propias, ya sea que las dejen intactas o les realicen algunas modificaciones. También se presenta el caso de apropiaciones consentidas cuando algunos miembros de este pueblo indígena tácitamente autorizan la apropiación de su creación al aceptar modificaciones a sus creaciones y realizar los tejidos de acuerdo con las directrices que les dan actores externos a los de su pueblo, situación que viene sucediendo reiteradamente hace varios años.

En el caso del sombrero vueltiao se identifica una posible apropiación no consentida de parte de empresas de origen chino, al producirlos en material sintético sin la debida autorización de los miembros de este pueblo indígena. La entrada de casi un millón de sombreros al país prendió las alarmas de los pueblos indígenas creadores y productores de este sombrero, pues fueron vendidos en la versión de fibra plástica tejida a máquina, en contraste con los originales, tejidos en caña flecha y hechos a mano. Los sombreros sintéticos se vendieron a turistas incautos especialmente en las ciudades del norte del país en época de fiesta y carnaval a precios muy bajos, convirtiéndolas en piezas desechables o de corto uso en el tiempo.

Por otra parte, al parecer también está la apropiación no consentida del Estado cuando las creaciones de los pueblos indígenas son asumidas por las organizaciones estatales como propias, al considerar que se ha definido que en primera instancia el titular de la denominación de origen "es el Estado colombiano en cabeza de la SIC"19.

Asimismo, son múltiples los casos de empresas nacionales o internacionales que buscan en los pueblos indígenas posibilidades novedosas para aplicar en los productos de vestuario, bisutería y objetos del hogar en los aspectos más simbólicos y estéticos de los pueblos originarios.

A nivel general, se considera que estos mecanismos de implementación de derechos de propiedad intelectual sobre artesanías indígenas tienen una estructura que pueden propiciar procesos de dependencia institucional, cultural, económica, jurídica y política al vincular a los diversos pue- blos indígenas artesanales con marcas colectivas y denominaciones de origen.

En primera instancia, se crea una suerte de dependencias institucionales para su existencia y se considera válido el conocimiento indígena artesanal para su reconocimiento, si ha superado múltiples procesos burocráticos que se caracterizan por brindar una información que no es suficientemente comprendida por los pueblos artesanales. Por tanto, la información que imparten estas instituciones es ambigua porque posiblemente no existe una comprensión crítica y profunda en relación con estos mecanismos de protección. De otra parte, para que el Estado implemente estos mecanismos de protección de la propiedad intelectual, es deseable que las comunidades o pueblos indígenas estén establecidos en asociaciones, forma organizativa que no necesariamente es representativa en estos pueblos, pero que propicia procesos más eficientes para su control. En la práctica estos pueblos existen si son reconocidos y avalados por estas instituciones normalizadoras.

Por otra parte, cuando los pueblos indigenas artesanales se vinculan a estas formas de reconocimiento de la propiedad intelectual es confuso saber a nombre de quién (o quiénes) debe quedar la titularidad de estas marcas y denominaciones de origen, asunto problemático porque todo el conocimiento histórico, de creación y del oficio queda en manos diferentes a la de sus dueños originarios, sin tener control de las trayectorias o la disposición final de la titularidad de estos conocimientos. En relación con las marcas colectivas, estas tienen términos de vigencia que deben refrendarse, lo cual también propicia grandes sospechas acerca de su permanencia y de su privatización, pues existen términos en el tiempo en que se posibilita la venta de estas marcas y denominaciones de origen a otros actores sociales. De otra parte, el conocimiento artesanal indígena se considera de dominio público ${ }^{20}$, aspecto también problemático porque estos conocimientos pueden ser utilizados sin límite alguno por otros actores sociales.

La implementación de estos derechos de propiedad intelectual también propicia procesos de dependencia cultural. Al estar regidos por instituciones que son ajenas a los pueblos indígenas se están generando inseguridades acerca de las prácticas en estos pueblos, por esta razón cada mente la titularidad de particulares" (Quiroz, s.f., p. 4). 
vez más esperan seguir lineamientos ajenos. Es el caso de los ámbitos de creación, en que los artesanos deben optar por criterios de diseño y de calidad emitidos por los profesionales del diseño que parten de referentes culturales de los pueblos pero que al modificar estas creaciones pueden quedar a nombre del Estado o privatizado por el diseñador externo. Este aspecto tiene incidencia en los ámbitos de sostenibilidad y trascendencia cultural de estos pueblos.

lgualmente, se están propiciando dependencias económicas, pues los pueblos deben pagar tarifas establecidas para la continuidad de su hacer creativo con compromisos económicos que nunca habían tenido, entonces surge la inquietud acerca de su permanencia si no tienen los recursos para pagarlas. Esta situación también puede generar dependencias del mercado, porque aquellos grupos productores que no tengan etiquetas con sus marcas, posiblemente no serán reconocidos por los compradores, a quienes se les orienta comprobar la autenticidad de un objeto artesanal solo a través de estas marcas.

En estos procesos de institucionalización también se pueden propiciar dependencias juridicas, porque las normas y leyes solo protegerán a aquellos que han asumido estos compromisos de propiedad intelectual, en un tremendo proceso de exclusión de aquellos que no los han asumido, aunque la ley debería proteger a todos en igualdad de condiciones. Asimismo, en estos escenarios no faltarán actores externos que pretendan tener en este recurso de protección un botín electoral, lo que propiciaría posibles dependencias políticas que se negociarían por votos o favores políticos, en una expresión de clientelismo autoritario.

\section{Necesidad de protección a las creaciones colectivas artesanales indígenas}

Actualmente pueblos originarios como los Wayuu y Zenú se encuentran en escenarios no pensados respecto a los derechos de propiedad intelectual, los cuales se caracterizan por contar con visiones muy diferentes a sus leyes de origen con la imposición de una sola cosmovisión sobre ellos. La propiedad intelectual con sus marcas colectivas y denominaciones de origen se ha construido y desarrollado sobre la base del individuo y de su propiedad, con la idea de negocio basada en la innovación y la creación de nuevas formas de consumo.
De manera muy diferenciada, los pueblos originarios han permanecido sobre la base del conocimiento tradicional con creaciones colectivas y anónimas que hacen parte de su legado ancestral artesanal. La necesidad de construir posibilidades para la protección a nivel nacional e internacional de las creaciones hechas con las manos de los pueblos originarios es fundamental para garantizar su permanencia y fortalecer sus identidades culturales. Para ello será necesario partir del conocimiento, reconocimiento y respeto de las leyes de origen de sus creaciones artesanales, conocer las experiencias propias de protección de sus creaciones, documentar los procesos de apropiación consentida y no consentida de las creaciones artesanales y fortalecer los procesos de autonomía y de organización comunitaria de los artesanos y artesanas de los pueblos indigenas del país.

Actualmente surgen grandes dudas relacionadas con la protección a partir de la formulación y puesta en marcha del programa "Implementación de los derechos de propiedad intelectual de las artesanías emblemáticas de Colombia” (Artesanías de Colombia, 2011), algunas de ellas son: ¿Cuáles son las lógicas que subyacen a estas supuestas medidas de protección? ¿Quiénes toman las decisiones en relación con las medidas de marcas colectivas y denominaciones de origen? ¿A quiénes benefician estas medidas de protección? ¿Estos mecanismos son de tipo moral, jurídico o económico? ¿Cómo es la protección en los niveles nacional, regional o global? ¿Qué tan informados están los pueblos originarios acerca de estos mecanismos de propiedad intelectual? ¿Qué tanto participan los pueblos indígenas en la toma de decisiones en relación con estos mecanismos de protección?

\section{Referencias}

ACNUDH, Alto Comisionado de las Naciones Unidas para los Derechos Humanos (s.f.) El derecho de los pueblos indigenas a la consulta previa, libre e informada. Una guía de información y reflexión para su aplicación desde la perspectiva de los Derechos Humanos. Bogotá: ACNUDH. USAID.

Artesanías de Colombia (2010). La artesanía y el derecho de autor. Bogotá: Artesanías de 
Colombia. Ministerio de Comercio, Industria y Turismo.

Artesanías de Colombia (2011). Implementación de los derechos de propiedad intelectual de las artesanías emblemáticas de Colombia. Bogotá: Artesanías de Colombia. Recuperado el 9 de mayo de 2024 de http://www.artesaniasdecolombia.com.co/propiedadintelectual/

El Colombiano (enero 12, 2013). No al vueltiao made in China. Recuperado el 12 de mayo de 2013 de http://www.elcolombiano.com/ BancoConocimiento/N/no_al_vueltiao_made_in_china/no_al_vueltiao_made_in_china.asp?pag=2\&todos $=1$

El Espectador - Cultura (diciembre 15, 2009). Sofisticación Wayuu. Recuperado el 19 de mayo de 2014 de http://www.elespectador. com/publicaciones/summus/articulo177567sofisticacion-wayuu

El Heraldo (marzo 29, 2014). Stella Rittwagen incluyó en su colección mochilas iguales a las de esta etnia, al parecer, sin su debida identificación. Palabras de Zenaida Pana. Mochilas wayuu, en el centro de polémica. Recuperado el 29 de marzo de 2014 de http:// elheraldo.co/tendencias/mochilas-wayuuen-el-centro-de-polemica-147635

Gudynas, E. (febrero, 2013). Extracciones, extractivismos y extrahecciones. Un marco conceptual sobre la apropiación de recursos naturales. Observatorio del Desarrollo, 18. CLAES. Recuperado el 20 de mayo de http:// www.extractivismo.com/documentos/GudynasApropiacionExtractivismoExtraheccionesOdeD2013.pdf

Gundermann, K. (2004). El método de los estudios de caso. Observar, escuchary comprender sobre la tradición cualitativa en la investigación social. México: Facultad Latinoamericana de Ciencias Sociales. El Colegio de México, 251-288.

Gabriel, L. y López, G. (2005). Introducción: Algunos referentes teóricos. Autonomías indígenas en América Latina: nuevas formas de convivencia política. México: Plaza y Valdés.

Hammen, C. M. van der (2003). The indigenous resguardos of Colombia: their contribution to conservation and sustainable forest use. Amsterdam: Netherlands Committee for IUCN. Jacanamijoy, J. C. (2012). Documento base para la implementación de planes, programas y proyectos hacia la autonomía artesanal en el pueblo indigena Kamsá del municipio de Sibundoy, Putumayo, Colombia. Sibundoy: documento de trabajo.

Khor, M. (2003). El saqueo del conocimiento. Propiedad intelectual, biodiversidad, tecnología y desarrollo sostenible. Barcelona: Icaria Editorial e Intermon Oxfam.

Ley del Artesano (1984). Ley 36 de 1984. Capítulo 1. Bogotá: Artesanías de Colombia.

Molano, A. (noviembre 22, 2009). Mochilas al viento. , El Espectador, 39.

OMP1 (s.f.) Propiedad intelectual y expresiones culturales tradicionales o del folclore. Folleto número 1, Organización Mundial de la Propiedad Intelectual. Recuperado el 3 de abril de 2014 de http://www.wipo.int/export/sites/www/freepublications/es/tk/913/ wipo_pub_913.pdf

OMP1, Organización Mundial de la Propiedad Intelectual (2008). Comité Intergubernamental sobre Propiedad Intelectual y Recursos Genéticos, Conocimientos Tradicionales y Folclore. Undécima sesión. Ginebra: OMPI.

OMPl, Organización Mundial de la Propiedad Intelectual (s.f.) ¿Qué es la propiedad intelectual? Ginebra: 0MPı. Recuperado el 8 de mayo de 2014 de http://www.wipo.int/export/sites/ www/freepublications/es/intproperty/450/ wipo_pub_450.pdf

Pineda, R. (1995). Pueblos indígenas de Colombia. Una aproximación a su historia, economía y sociedad. Tierra profana. Grandes proyectos en territorios indigenas de Colombia. Bogotá: Editorial Disloque.

Pulzo (abril 2, 2014). Diseñadora que se apropia de mochilas Wayuu advierte que reaccionará ante 'falsedades'. Recuperado el 24 de abril de 2014 de http://www.pulzo.com/estilo/ disenadora-que-se-apropia-de-mochilaswayuu-advierte-que-reaccionara-ante-falsedades-111251

Quiroz, A. (s.f.) Propiedad del Estado y recursos naturales. Documento de trabajo. Recuperado el 12 de junio de 2014 de http://www. alexanderlopez.com.co/sitio/wp-content/ uploads/2012/01/Propiedad-de-los-recursos-naturales-en-Colombia.pdf

Ramírez, M. (1990). Cartilla Wayuu. Bogotá: Artesanías de Colombia. Ministerio de Comercio, Industria y Turismo.

Revista Antropologika (octubre 10, 2011). Apropiación cultural de diseños Wayuu en la Revista 
Vogue. Recuperado el 19 de mayo de 2014 de http://antropologika.com/2011/10/10/ disenadora-en-vogue-presenta-disenoswayuu-como-suyos/

Revista Cromos (2009). Diseños de ataque. Recuperado el 2 de mayo de 2014 de http://www. cromos.com.co/tendencias/moda/articulodisenos-de-ataque
Wayunkerra Epinayu (2014). Susu Wayuu, Mochila Wayuu, Wayuu Bag: así se 'roban' el patrimonio cultural Wayuu. Recuperado el 19 de mayo de 2014 de http://wayunkerra. blogspot.ch/2014/03/susu-wayuu-mochilawayuu-wayuu-bag-asi.html 